\title{
Dextrans produced by lactic acid bacteria exhibit antiviral and immunomodulatory activity against salmonid viruses
}

\author{
Montserrat Nácher-Vázquez ${ }^{\mathrm{a}}$, Natalia Ballesteros ${ }^{\mathrm{a}}$, Ángeles Canales ${ }^{\mathrm{a}}$, Sylvia Rodríguez \\ Saint-Jean ${ }^{\mathrm{a}}$, Sara Isabel Pérez-Prieto ${ }^{\mathrm{a}}$, Alicia Prieto ${ }^{\mathrm{a}}$, Rosa Aznar ${ }^{\mathrm{b}, \mathrm{c}}$, Paloma López $^{\mathrm{a}, *}$
}

${ }^{\text {a }}$ Centro de Investigaciones Biológicas, C.S.I.C., Ramiro de Maeztu 9, 28040 Madrid, Spain

${ }^{\mathrm{b}}$ Instituto de Agroquímica y Tecnología de los Alimentos, C.S.I.C, Agustín Escardino 7, 46980 Paterna, Valencia, Spain

${ }^{\mathrm{c}}$ Departamento de Microbiología y Ecología. Universidad de Valencia, Doctor Moliner 50, 46100 Burjassot, Valencia, Spain

*Corresponding author. Tel.: +34 918373112 Ext. 4202; fax: +34 915360432

E-mail address: plg@ cib.csic.es

\begin{abstract}
Abbreviations: $\mathrm{BF}-2$, bluegill fry; $\mathrm{CC}_{50}$, dextran concentration provoking $50 \%$ inhibition of cell growth; CDM, defined medium containing $0.8 \%$ glucose; CDMS, CDM without glucose and supplemented with $0.8 \%$ sucrose; $\mathrm{TCID}_{50} \mathrm{~mL}^{-1}$, virus titer infecting $50 \%$ of the cell culture; DOSY, diffusion ordered spectroscopy; $\mathrm{EC}_{50}$, dextran concentration reducing the viral cytopathic effect to $50 \%$ of control value; EPC, epithelioma papulosum cyprinid; EPS, exopolysaccharide; FBS, fetal bovine serum; HK, head kidney; IHNV, infectious hematopoietic necrosis virus; IPNV, infectious pancreatic necrosis virus; IR, infrared, LAB, lactic acid bacteria; MM, L15 medium with 2\% FBS; MOI, multiplicity of infection; MRS, Man Rogosa Sharpe broth; MRSS, MRS medium supplemented with 2\% sucrose instead of glucose; NMR, nuclear magnetic resonance; PBS, Phosphate buffered saline; qPCR, quantitative real time PCR polymerase change reaction; RT-qPCR, reverse transcription qPCR; SI, selective index.
\end{abstract}




\section{Abstract}

2 Viral infections in the aquaculture of salmonids can lead to high mortality and 3 substantial economic losses. Thus, there is industrial interest in new molecules active 4 against these viruses. Here we describe the production, purification, and the 5 physicochemical and structural characterization of high molecular weight dextrans 6 synthesized by Lactobacillus sakei MN1 and Leuconostoc mesenteroides RTF10. The 7 purified dextrans, and commercial dextrans with molecular weights ranging from 10$82000 \mathrm{kDa}$, were assayed in infected BF-2 and EPC fish cell-line monolayers for 9 antiviral activity. Only T2000 and dextrans from MN1and RTF1 had significant 10 antiviral activity. This was similar to results obtained against infectious pancreatic 11 necrosis virus. However the dextran from MN1 showed ten-fold higher activity against 12 hematopoietic necrosis virus than T2000. In vivo assays using the MN1 polymer 13 confirmed the in vitro results and revealed immunomodulatory activity. These results 14 together with the high levels of dextran production $\left(2 \mathrm{~g} \mathrm{~L}^{-1}\right)$ by Lb. sakei $\mathrm{MN} 1$, indicate 15 the compounds potential utility as an antiviral agent in aquaculture.

16 Keywords: Lactic acid bacteria, exopolysaccharide, dextran, antiviral, 17 immunostimulants, salmonid virus, IPNV, IHNV. 


\section{Introduction}

Salmonid fish viruses cause considerable losses to the aquaculture industry worldwide. Aquabirnaviruses such as the infectious pancreatic necrosis virus (IPNV), and novirhabdoviruses such as infectious hematopoietic necrosis virus (IHNV), cause acute diseases of rainbow trout (Onchorhynchus mykiss) and several species of salmon. The mortalities are inversely proportional to the age of the fish and survivors remain carriers of the virus for long periods. IPNV was the first virus isolated from fish, in 1960, and is considered the most widely distributed aquatic virus (Rodríguez Saint-Jean, Borrego, \& Pérez-Prieto, 2003). IHNV was first observed on the west coast of the USA in cultivated sockeye salmon (Oncorhynchus nerka) in 1953, and has been also isolated in Japan and several European and Asian countries (Bootland \& Leong, 1999).

The use of existing antivirals against fish viruses has not been investigated in depth due to high product costs and potential toxicity. Alternative antivirals have been proposed such as olive leaf extract (Micol et al., 2005) and milk casein (Rodríguez Saint-Jean et al., 2012). Prevention and control of disease is currently approached in fish farming by the use of immunostimulants such as $\beta$-glucans from yeast, fungi or bacterial origin, alone or supplemented with other compounds (for example: mannose, LPS or vitamin C) (Ring ø, Olsen, González-Vecino, Wadsworth, \& Song, 2012). Thus, alternative antiviral molecules that could block replicating virus in infected individuals are of great interest in the battle against virus infections. Ideally, these new drugs should induce strong and specific inhibition of virus replication without affecting cellular processes. Among them, polysaccharides besides $\beta$-glucans, could have antiviral activity and this possibility deserves to be investigated. 
Many lactic acid bacteria (LAB) produce exopolysaccharides (EPS) with different compositions, structures, molecular masses and conformations. These compounds have many industrial applications. High molecular weight polysaccharides are widely used in the food industry as texturizers, stabilizers, viscosifiers, and emulsifiers among other applications (Ruas-Madiedo \& de los Reyes-Gavilán, 2005; Werning et al., 2012). Dextrans are used in the production of fine chemicals such as plasma substitutes and viruses in aquaculture due to the harmless nature of these compounds.

Dextrans are composed of repeating units that contain only D-glucopyranose and the linkages in the main chain are $\alpha-1,6$. In addition, they may have side-chain branches that involve other $\alpha$-linkages different from that in the main chain $(\alpha-1,2 ; \alpha-1,3$ or $\alpha$ 1,4). These polymers are synthesized and secreted by LAB and they are produced by strains belonging to the genera Lactobacillus, Leuconostoc, Streptococcus and Weisella (Leemhuis et al., 2013). The dextran most widely used in industry contains $95 \% \alpha-1,6$ and 5\% $\alpha-1,3$ linkages and is synthesized by Leuconostoc mesenteroides NRRL B512F. This was the first industrial dextran produced for different medical and biotechnological applications (Naessens, Cerdobbel, Soetaert, \& Vandamme, 2005). In the present study, we have characterized as dextran the EPS produced by $L b$. sakei MN1, evaluated the in vitro and in vivo antiviral activity of the purified EPS against IHNV and IPNV and investigated its mechanism of action. 


\section{Materials and Methods}

62

63

64

65

66

67

68

69

70

71

72

73

74

75

76

77

\subsection{Bacterial strains and growth media}

The two LAB strains used in this work were isolated from meat products at the Department of Food Biotechnology, Institute of Agrochemistry and Food Technology (C.S.I.C., Valencia, Spain).They were characterized and identified as Lb. sakei MN1 and Lc. mesenteroides RTF10 by $16 \mathrm{~S}$ rRNA coding gene sequencing (accession number in GenBank: KJ161303 and KJ161304, respectively) at Secugen (Madrid, Spain). The strains were grown at $30^{\circ} \mathrm{C}$ without agitation in defined CDM medium (Poolman, Hellingwerf, \& Konings, 1987) supplemented with 0.8\% sucrose (CDMS) instead of glucose or in Man Rogosa Sharpe broth (MRS, De Man, Rogosa, \& Sharpe, 1960) supplemented with 2\% sucrose (MRSS) instead of glucose. Strains were kept in MRS supplemented with $20 \%$ (v/v) glycerol for long-term storage and maintained at $-80{ }^{\circ} \mathrm{C}$.

\subsection{Quantification, purification and characterization of EPS}

EPS production was determined in liquid media. Strains were grown in MRSS to an $\mathrm{OD}_{600 \mathrm{~nm}}$ of 2. Cells were washed, resuspended in the same volume of fresh MRSS media and diluted 1:100 in CDMS medium. Batch fermentations without $\mathrm{pH}$ control were performed, in triplicate, for the two strains and they were grown in $100 \mathrm{~mL}$ screwcapped flasks for $10 \mathrm{~h}$ at $30{ }^{\circ} \mathrm{C}$. Cultures were sampled every hour to monitor growth and EPS production. For EPS quantification, bacterial cells were removed from the growth medium by centrifugation at $9,300 \times \mathrm{g}$ for $10 \mathrm{~min}$ at $4{ }^{\circ} \mathrm{C}$. The EPS was precipitated from the supernatants by the addition of three volumes of cold absolute ethanol and incubation for 12 hours at $-20^{\circ} \mathrm{C}$. After centrifugation at 9,300 x $g$ for 20 min at $4{ }^{\circ} \mathrm{C}$, the precipitate was washed twice with $80 \%$ ethanol and sedimented by 
centrifugation. The EPS pellet was air dried, then suspended in distilled water and heated for $10 \mathrm{~min}$ at $30^{\circ} \mathrm{C}$. Total sugar content was determined by the phenol/sulphuric acid method using glucose as standard (Dubois, Gilles, Hamilton, Rebers, \& Smith, 1956). Determinations were performed in duplicate. EPS large scale production and purification was performed as previously described (Notararigo et al., 2013). Briefly, LAB strains were grown in MRS supplemented with $2 \%$ sucrose to an $\mathrm{OD}_{600 \mathrm{~nm}}$ of 1.0 for L. mesenteroides RTF10 or of 2.5 for L. sakei MN1. Cells were removed from culture supernatant by centrifugation and EPS were recovered by precipitation with an equal volume of ethanol at $96 \%$ and centrifugation. Then, the EPS were resuspended in water and were purified by dialysis using a membrane (12-14 $\mathrm{kDa}$ cutoff) and chromatographic fractionation through a Sepharose CL-6B column. After this purification the yield of the EPS were $1.2 \mathrm{~g} \mathrm{~L}^{-1}$ for MN1 and $0.8 \mathrm{~g} \mathrm{~L}^{-1}$ for RTF10 strains and the levels of contaminant DNA, RNA and proteins were below the detection levels $\left(0.5 \mu \mathrm{g} \mathrm{mL}^{-1}, 20 \mathrm{ng} \mathrm{mL} L^{-1}\right.$ and $\left.1 \mu \mathrm{g} \mathrm{mL}^{-1}\right)$ by use of specific fluorescent staining kits and the Qubit ${ }^{\circledR} 2.0$ fluorometric detection methods (Molecular probes). EPS structure was analyzed by different approaches that included monosaccharide composition, phosphate content, methylation analysis and infrared (IR) spectra using the same protocols described by Notararigo et al. (2013). For nuclear magnetic resonance (NMR) analysis, EPS $(15 \mathrm{mg})$ were dissolved in deuterated water $(0.5 \mathrm{~mL})$. The magnitude of the molecular mass of the EPS was estimated by diffusion ordered spectroscopy (DOSY). The standard Bruker DOSY protocol was used at $298 \mathrm{~K}$ with the ledbpg2s pulse sequence on an Avance $500 \mathrm{MHz}$ spectrometer. Thirty-two 1D ${ }^{1} \mathrm{H}$ spectra were collected with a gradient duration of $\delta=4 \mathrm{~ms}$ and an echo delay of $\Delta=400 \mathrm{~ms}$. Samples 
of commercially available dextrans with different molecular weights were used to build 108 the calibration curve.

\subsection{Antiviral activity assay against IHNV and IPNV}

\subsubsection{Fish cell lines and viruses}

Experiments were performed using the bluegill fry (BF-2) fish cell line from Lepomis macrochirus (ATCC, CRL 1681) and epithelioma papulosum cyprinid (EPC) cells from Pimephales promelas (ATCC, CRL 2872). Both cell lines were grown in Leibovitz medium (L15; Gibco, Invitrogen, Barcelona, Spain) supplemented with $100 \mathrm{U}$ $\mathrm{mL}^{-1}$ penicillin, $100 \mu \mathrm{g} \mathrm{mL} \mathrm{m}^{-1}$ streptomycin, $2 \mathrm{mM} \mathrm{L}$-glutamine and $10 \%$ fetal bovine serum (FBS; Gibco, Invitrogen) at $25^{\circ} \mathrm{C}$. Maintenance medium was based on the L15 medium with only $2 \%$ FBS (MM). For antiviral activity assay, the VR714 strain of IHNV and the Sp serotype of IPNV were obtained from the American Type Culture Collection (ATCC VR714 and ATCC VR1318, respectively). For virus propagation the protocols and methods were performed as previously described (Rodríguez Saint-Jean presence of different dextran concentrations for 3 (BF-2) or 7 (EPC) days at $20{ }^{\circ} \mathrm{C}$.

Cells were fixed and stained using $1 \%$ crystal violet in $20 \%$ ethanol, then the cells were 
microplate reader (BIORAD, Hercules, CA, USA) at $590 \mathrm{~nm}$. Results were expressed as percentage of surviving cells, where $100 \%$ represents the dye absorbance of the control cells incubated in MM.

\subsubsection{Antiviral activity assay}

Antiviral activity was determined as previously described (Rodríguez Saint-Jean \& Pérez-Prieto, 2006). Cells were seeded in 96-well culture plates and for each treatment a mock-infected control was included (toxicity controls) and some cell wells were left untreated and infected (virus control). When the control virus wells affected more than $80 \%$ of the cell monolayer, the cells were processed by the colorimetric assay described above. Inhibition of the viral cytopathic effect on the dextran treated cells was measured as percentages, where $100 \%$ inhibition represents the average of the dye absorbance value of non-infected cells treated in the same way as infected cells.

\subsubsection{Virus yield reduction assay} infection (MOI) of 0.1 and, after $1 \mathrm{~h}$ adsorption at $20^{\circ} \mathrm{C}$ or $15{ }^{\circ} \mathrm{C}$ respectively, the inoculum was removed, the monolayers washed with phosphate buffered saline (PBS), and various concentrations of EPS were added. At 3 or 5 days after infection with IPNV or IHNV, the cultures were frozen and thawed three times to lyse the cells, centrifuged (3000 x $g, 10 \mathrm{~min}$ ), and the supernatants stored at $-70{ }^{\circ} \mathrm{C}$ until they were used for viral 151 titration. The total yield (intracellular and extracellular) of infectious virus was determined by infecting four parallel well of cell monolayers with ten-fold dilutions of the samples.

\subsubsection{Addition time assay}


BF-2 or EPC cells $\left(5 \times 10^{4}\right.$ cells per well) were seeded in 48 -well plates and

156 pretreated with dextrans $\left(1000 \mu \mathrm{g} \mathrm{mL}^{-1}\right)$ for $30 \mathrm{~min}$ before, simultaneously to or $1 \mathrm{~h}$ 157 after infection with IPNV or IHNV at a MOI of 0.1 . The cultures (in quadruplicate) 158 were incubated for 3 days after infection, and the cells were then recovered by scraping. 159 Following three consecutive freeze-thaw cycles, the supernatants of the clarified lysates 160 were collected, and the amount of infectious virus was determined by TCID 50 assay.

161 For a direct viricidal test, samples were first mixed with an equal volume of the IHNV or IPNV suspension (at a final dose of $100 \mathrm{TCID}_{50} \mathrm{~mL}^{-1}$ ) and incubated for $1 \mathrm{~h}$ at $15{ }^{\circ} \mathrm{C}$ (IHNV) or $20{ }^{\circ} \mathrm{C}$ (IPNV). The amount of infectious virus was determined by $164 \mathrm{TCID}_{50}$ assay.

\subsection{In vivo assay}

\subsubsection{Experimental fish}

The rainbow trout fry, mean body weight $1.5 \mathrm{~g}$, were purchased from a commercial fish farm with no history of viral disease. The fish were kept under a 12/12 h light/dark regime at $15{ }^{\circ} \mathrm{C}$ in $350 \mathrm{~L}$ closed tanks with re-circulating water (Living Stream, Frigid Units Inc, Ohio) at the Centro de Investigaciones Biológicas (Madrid, Spain). The fish were fed (3\% of their body weight) twice a day with a diet of commercial pellets and they were maintained as described previously Pérez-Prieto et al. (2001).The trout were anaesthetized by immersion in $50 \mu \mathrm{g} \mathrm{mL}^{-1}$ buffered tricaine methanesulphonate (MS222; Sigma) prior to handling. The experiments described comply with the Guidelines of the European Union Council (86/609/EU) for the use of laboratory animals. 
and control fish. Group 1 and 2: treated with $10 \mu \mathrm{g}$ per fish of EPS diluted in saline solution during three day. Group 3 and 4 treated with $50 \mu \mathrm{g}$ per fish of EPS diluted in saline solution during three days. EPS administration was performed using an automatic pipette with a $20 \mu \mathrm{L}$ tip which was introduced into the mouth of each fish, supporting 182 the tip end at the entrance of the oesophagus. Group 5, 6 and 7 were maintained during 3 days without treatment.

On the third day of treatment the fish belonging to groups 1, 3 and 5 were infected by immersion in IHNV $\left(5 \times 10^{5} \mathrm{TCID}_{50} \mathrm{~mL}^{-1}\right)$ as previously described (De Las Heras, Rodríguez Saint-Jean, \& Pérez-Prieto, 2010). The fish of groups 2, 4 and 6 were infected by immersion in IPNV $\left(5 \times 10^{5} \mathrm{TCID}_{50} \mathrm{~mL}^{-1}\right)$. Normal control (Groups 7), IHNV control (Group 5) and IPNV control (Group 6) underwent the same stress handling without the antiviral compound. Water-quality parameters were maintained at optimum levels, and the culturing conditions in all tanks were equivalent. All groups were kept under observation for 30 days to record clinical signs and mortality rate. Two replicas of the trial were performed.

Relative percentage survival was calculated 30 days after challenge according to the following formula 1-[\% mortality of fish given vaccine/mortality of virus control fish $] \times 100$.

\subsubsection{Gene expression analysis}

Two fish groups were used for in vivo stimulation. Two groups were injected intraperitoneally with either EPS from MN1 $\left(50 \mu \mathrm{g} \mathrm{mL}^{-1}\right)$ or poly I:C $\left(25 \mu \mathrm{g} \mathrm{mL}^{-1}\right)$ and other group was injected with $100 \mu \mathrm{L}$ PBS per fish. At days 1, 3, 7 and 15 after treatment, fish $(n=3)$ from each group were randomly sampled and killed with MS-222. 
expression of selected genes (IFN-1 and IFN- $\gamma$ ) by reverse transcription quantitative real time PCR analysis (RT-qPCR).

Total RNA extraction was carried out using Trizol (Invitrogen) according to the manufacturer's instructions. A Nanodrop ND 1000 spectrophotometer was employed to analyze RNA concentration and purity. All samples were DNase treated to remove any contaminating DNA.

cDNA was synthesized using the SuperScript III First - Strand Synthesis System (Invitrogen, Madrid, Spain) with random primers in a $20 \mu \mathrm{L}$ final reaction volume. The qPCR were performed by using the SYBR ${ }^{\circledR}$ green method, in an iQ5 iCycler thermal cycler (Bio-Rad Laboratories, Madrid, Spain). The qPCR amplifications were carried out in 96-well plates by mixing $1 \mu \mathrm{L}$ of four-fold diluted cDNA, $12.5 \mu \mathrm{L}$ of $2 \mathrm{x}$ concentrated iQ SYBR Green Super Mix (Bio Rad), $0.3 \mu \mathrm{M}$ forward primer and $0.3 \mu \mathrm{M}$ of reverse primer in $25 \mu \mathrm{L}$ reaction volume for each sample. The thermal profile was 10 min at $95^{\circ} \mathrm{C}$ followed by 40 amplification cycles of $10 \mathrm{~s}$ at $95^{\circ} \mathrm{C}, 1 \mathrm{~min}$ at $60{ }^{\circ} \mathrm{C}$ and a dissociation cycle $\left(1 \mathrm{~min}\right.$ at $95^{\circ} \mathrm{C}$ and $1 \mathrm{~min}$ at $\left.60{ }^{\circ} \mathrm{C}\right)$. After the run, the melting curve of each amplicon was examined to determine the specificity of the amplification. All qPCR reactions were performed in triplicate and for each mRNA, gene expression values were normalized to that of the endogenous control (elongation factor 1- $\alpha$ ). The folds change relative to control expression were calculated by the $2^{-\Delta \Delta \mathrm{Ct}}$ method (Livak \& Schmittgen, 2001), where $\Delta \Delta \mathrm{Ct}_{\text {gene }}=\Delta \mathrm{Ct}$ gene - mean $\Delta \mathrm{Ct}_{\text {control. }}$

The qPCR primers used were IFN1F (5'AAAACTGTTGATGGGAATATGAAA-3') and IFN1R (5'CGTTTCAGTCTCCTCTCAGGTT-3') for IFN-1, IFNR (5'CTGAAAGTCCACTATAAGATCTCCA-3') and IFN $\gamma \mathrm{R}$ (5'- 
226 CCCTGGACTGTGGTGTCAC-3') for IFN- $\gamma$ and, EF-F (5'-

227 GATCCAGAAGGAGGTCACCA-3') and EF-R (5'-TTACGTTCGACCTTCCATCC-

228 3') for elongation factor $1-\alpha$.

$229 \quad$ Statistical Analysis

230 Data are presented as mean \pm standard deviation. Factorial ANOVAs were run to

231 determine if the differential expression gene differed between the dextran treated and

232 untreated groups. The $\mathrm{p}$ values $<0.05$ were considered significant. 


\section{Results}

234

235

236

237

238

239

240

241

242

243

244

245

246

247

249

250

251

252

253

254

255

256

\subsection{EPS production and characterization}

The rate of EPS production by the two strains in defined CDMS medium supplemented with sucrose was monitored during $10 \mathrm{~h}$ and is shown in Fig. 1. Both strains synthesized EPS during the exponential phase of growth. Maximum production was $2 \mathrm{~g} \mathrm{~L}^{-1} \pm 0.1 \mathrm{~g} \mathrm{~L}^{-1}$ for Lb. sakei MN1 (EPS-LS) and $1.4 \mathrm{~g} \mathrm{~L}^{-1} \pm 0.05 \mathrm{~g} \mathrm{~L}^{-1}$ for Lc. mesenteroides RTF10 (EPS-LM). Both EPS were purified for further analysis. The IR spectra of the two EPS preparations, and the commercial T2000 dextran, were essentially the same (Fig. 2A and Notararigo et al., 2013) and they were typical of carbohydrates, with an absorption band around $850 \mathrm{~cm}^{-1}$ and another at $916 \mathrm{~cm}^{-1}$ both attributable to $\alpha$-anomers. Observation of the signals defined further some chemical characteristics of these compounds. In the methylation studies the two EPS gave the partially methylated and partially acetylated derivates of a (1-6) glucan with approximately $6 \%$ substitution, at positions $O-3$, by side chains composed of a single residue of glucose (Fig. 2B and Notararigo et al., 2013). The data from methylation analysis and IR spectra defined the polymer as a dextran-type polysaccharide with the structure depicted in Fig. 2C. According to the DOSY analysis the two bacterial dextrans, EPS-LS and EPS-LM, had similar molecular masses (data not shown). When they were compared with the commercial dextran T2000 (EPS-LS and T2000 analysis is shown in Fig. 3), a great difference in molecular mass was detected, with a logarithmic diffusion coefficient of -10.9 for T2000 and -12.3 for the two EPS tested. T2000 is a high purity dextran fraction commercialized with the highest average molecular weight $\left(2 \times 10^{6} \mathrm{Da}\right)$ and molecular weight distribution. Thus, EPS-LS and EPS-LM have an average molecular weight $>2 \times 10^{6}$ Da. Due to this very high 
molecular weight a more precise determination could not be obtained by NMR nor by chromatographic analysis, since appropriate commercial molecular markers do not exist.

\subsection{Potential as antiviral agent against salmonid fish viruses}

The cytotoxicity of the purified EPS-LS and EPS-LM and T2000 dextrans was assayed against BF-2 and EPC fish cell line monolayers prior to the in vitro analysis of antiviral activity against IPNV and IHNV. The three dextrans proved not to be toxic up to the maximum concentration tested in this work $\left(5000 \mu \mathrm{g} \mathrm{mL}^{-1}\right)$. Once the non-toxic character of the dextrans had been ascertained, the inhibition of IPNV and IHNV fish viral infections was determined using a straightforward assay based on the reduction of the cytopathic viral effect. The three dextrans showed antiviral activity (Table 1) though differential behavior among them was observed. Selective index (SI) was calculated by the ratio $\mathrm{CC}_{50} / \mathrm{EC}_{50}$. At all concentrations assayed, the three dextrans showed a similar antiviral activity against IPNV virus (results not shown). A concentration of 1000 (for EPS-LS and EPS-LM) or 3000 (commercial dextran T2000) $\mu \mathrm{g} \mathrm{mL}^{-1}$ was required to obtain a 50\% inhibition (Table 1).

EPS-LS and EPS-LM showed a similar antiviral activity against the virus IHNV in the range of concentrations tested, in contrast to T2000 that showed a very low activity (Fig. 1S). In addition, EPS-LS showed the highest antiviral activity resulting in a 50\% inhibition at a concentration of $500 \mu \mathrm{g} \mathrm{mL}^{-1}$ (Table 1). A ten-fold higher concentration $\left(5000 \mu \mathrm{g} \mathrm{mL}^{-1}\right)$ of $\mathrm{T} 2000$ was required to obtain the same effect (Table 1). EPS-LS inhibits IHNV replication in EPC cells with a selective index of more than 10 . The more potent inhibition of EPS-LS and EPS-LM against IHNV could be explained by their molecular weight than T2000 (Fig. 3). Therefore, the antiviral action of commercial 
dextrans with a molecular weight ranging from 10-500 kDa (T10, T50, T70 and T500) was also analyzed (Table 1 and Fig. S1). No antiviral activity of T10, T50 and T7 against IPNV and IHNV was detected. Similarly, this reduction of the molecular weight of the commercial dextrans from $2000 \mathrm{kDa}$ to $500 \mathrm{kDa}$ almost abolished their influence on IPNV infection increasing the $\mathrm{EC}_{50}$ from 3000 to $>5000$ (Table 1) and provoking a reduction of infectivity from $50 \%$ for $\mathrm{T} 2000$ to $25 \%$ for $\mathrm{T} 500$ at a concentration of the dextrans of $1 \mu \mathrm{g} \mathrm{mL}^{-1}$ (Fig. 1S).

\subsection{Inhibitory effect on IPNV and IHNV infection by dextrans}

The influence of the polymers on the viruses' replication in cell cultures was analyzed by the viral yield reduction assay. For IPNV, a significant reduction in virus yield of 2.5 or 2 logarithmic units was recorded in the BF-2 cells treated with either EPS-LS or EPS-LM at the highest concentration tested $\left(1000 \mu \mathrm{g} \mathrm{mL}{ }^{-1}\right)$. The EPS-LS was the only dextran whose addition at $250 \mu \mathrm{g} \mathrm{mL} L^{-1}$ resulted in a decrease of viral infectivity (1 logarithmic unit). By contrast, for T2000 no significant influence in infective viral titre was observed at any concentration tested (Fig. 4A).

In the case of IHNV, a 4, 2 or 1.5 logarithmic units reduction in virus yield was

297 detected in the EPC cells treated with EPS-LS, EPS-LM or T2000 at $1000 \mu \mathrm{g} \mathrm{mL} \mathrm{L}^{-1}$. At lower doses (from 100 to $500 \mu \mathrm{g} \mathrm{mL}^{-1}$ ), the two EPS also reduced viral infectivity (in the range of 1.5 to 3.5 logarithmic units) with a greater effect of EPS-LS, whereas in this dose-range T2000 only produced a slight effect (0.5 logarithmic unit reduction) at $301500 \mu \mathrm{g} \mathrm{mL}^{-1}$ (Fig. 4B). 
To identify at which stage of the virus cycle the dextrans could impair viral infection, addition-time assays were performed using dextrans at a concentration of $1000 \mu \mathrm{g} \mathrm{mL}^{-1}$ (Fig. 5).

In BF-2 cells infected with IPNV, the addition of any of the three dextrans, 30 min prior to infection, elicited some antiviral activity (1 logarithmic unit for both EPS and 0.5 for T2000). Higher antiviral activity was observed when the dextrans were added at the time of infection or 60 min later. In these cases, in the BF-2 cells treated with EPSLS, EPS-LM or T2000, a decrease of approximately 2.5, 1.5 or 1 logarithmic units in virus yield was detected (Fig. 5A).

Similar behaviour was observed in the EPC cells infected with IHNV (Fig. 5B). However, in this case, the reduction in virus yield provoked by EPS-LS addition was much higher when this dextran was added at the time of exposure or $60 \mathrm{~min}$ after infection, with a reduction of viral infectivity of approximately 5 logarithmic units.

\subsection{The effect of EPS-LS on the survival of IPNV-and IHNV-infected rainbow trout}

Since EPS-LS showed the highest antiviral activity in vitro (Table 1 and Figs. 4 and

5), its influence at $10 \mu \mathrm{g} \mathrm{mL}^{-1}$ and $50 \mu \mathrm{g} \mathrm{mL}^{-1}$ was analyzed in vivo (Fig. 6). Dextranuntreated fry trout infected with IPNV began to show characteristic signs of infectious IPNV diseases from day 2 after infection (Fig. 6A). On this day mortality began in this group, increasing in a stepwise manner through days 4, 7, 11 and 13, and finally stopping around day 16. In infected fish treated with $10 \mu \mathrm{g} \mathrm{mL}^{-1}$ of EPS-LS, signs of the disease were observed on day 6 and deaths registered were 1 fish on day 7,1 fish on day 12 and 1 fish on day 19. In fish pretreated with EPS-LS at $50 \mu \mathrm{g} \mathrm{mL}^{-1}$ the signs of the disease were observed on day 6 and deaths registered were only 1 fish on day 7 . The non infected control fish showed a normal behaviour with a survival of $96 \%$ at the end 
327 of the experiment, whereas the accumulated mortality in untreated fish infected with

328 IPNV (positive control) were $53.3 \%$. In fish pretreated with 10 or $50 \mu \mathrm{g} \mathrm{mL}^{-1}$ of EPS-

329 LS the accumulative mortality was only of $20 \%$ and $6.6 \%$ respectively. Thus, EPS-LS

330 at $50 \mu \mathrm{g} \mathrm{mL}^{-1}$ increased the survival from $46.7 \%$ (untreated control) to $87.5 \%$.

331 Dextran-untreated fry infected with IHNV began to show characteristic signs of

332 infectious IHNV disease from day 5 after infection (Fig. 6B). On day 6 mortality began

333 in this group reaching a $33 \%$ on days 12 , a $60 \%$ on days 17 and a final value of $73 \%$ on

334 day 30. In infected fish treated with $10 \mu \mathrm{g} \mathrm{mL}^{-1}$ EPS-LS, signs of the disease started on

335 day 11 and deaths registered were 1 fish on days 11, 13, 15, 19 and 2 fish on day 21 . In

336 infected fish treated with $50 \mu \mathrm{g} \mathrm{mL}^{-1}$ EPS-LS, signs of the disease were observed on

337 day 11 and deaths registered were 1 fish, on days 12, 15 and 21 . The accumulated

338 mortality in untreated fish infected with IHNV was $73.3 \%$, whereas in fish pretreated

339 with 10 and $50 \mu \mathrm{g} \mathrm{mL}^{-1}$ was $40 \%$ and $20 \%$, respectively. Thus, pretreatment with $50 \mu \mathrm{g}$

$340 \mathrm{~mL}^{-1}$ EPS-LS raised the fish survival from $22.7 \%$ to $72.7 \%$.

341 3.6. Kinetics of differential expression of interferon genes in trout head kidney

342 To investigate the potential immunomodulatory activity of EPS-LS, expression of 343 the selected genes (IFN-1 and IFN- $\gamma$ ) was analyzed by RT-qPCR in trout head kidney $344(\mathrm{HK})$ at different times after treatment with the dextran. Because HK was the main trout internal immunological responsive organ, it was chosen to study the kinetics of expression of IFN.

The fold increases observed in $\mathrm{HK}$ of treated group in comparison to their corresponding untreated control group is shown in Fig. 7 for IFN-1 and IFN- $\gamma$ expression. In the case of IFN-1, the immunostimulant of innate response poly I:C was also tested as a control, and an up-regulation was observed 1 day after treatment, which 
351 decreased to almost control levels on day 2 (Fig. 7A). The EPS-LS produced an up-

352 regulation of the expression of both glycoproteins. As expected, accordance with the

353 involvement of the IFN tested, either an innate or adaptive immunological response to

354 EPS-LS was detected at different time points. The maximum value for IFN-1 transcript

355 was observed 3 days after treatment, reaching a level of 27.8 -fold over the untreated

356 control, higher than that induced by poly I:C (5.8-fold). Up-regulation mediated by

357 EPS-LS remained high at day 7 and decreased almost to control levels at day 15. By

358 contrast, and as expected for adaptive immune response, the IFN- $\gamma$ mRNA levels only

359 increased drastically at day 15 after treatment with EPS-LS. Thus, these results revealed

360 that the bacterial dextran immunomodulates trout in vivo. 
The early events in the replication cycle of some types of viruses are relevant to the design of antiviral compounds. However, the potential to induce immune responses is also relevant in fish, and could be important in delaying the progression of a viral infection. Thus, there is an increasing interest in the evaluation of glucans as immunomodulators, feed additives or adjuvants for vaccines in fish aquaculture. Studies have focused mostly on $\beta$-glucan activity against bacteria (Ai et al., 2007) or virus (Kim, Ke, \& Zhang, 2009; Beaulaurier et al., 2012) but the mechanisms by which the immunity is enhanced is not well known. Glucan receptors have been reported in fish macrophages (Engstad \& Robertsen, 1994; Ainsworth, 1994) and non-specific immunity by direct activation of macrophages has also been described (Sakai, 1999; Cook, Hayball, Hutchinson, Nowak, \& Hayball, 2001). More recently other researchers have reported some results on the immunological activities of $\beta$-glucans. Falco et al. (2013) described up-regulation of TLR3 dependent genes and an increased antiviral activity of Mx protein, in common carp fed with $\beta$-glucan supplemented diets and stimulated with poly I:C. namely, dextrans of bacterial origin. The EPS-LS and EPS-LM have shown in vitro and EPS-LS in vivo antiviral actions against fish viruses. Moreover, the in vitro experiments (Table 1, Figs. 4, 5 and 1S) indicated that the high molecular weight EPS LS and EPSLM exhibit some properties or mechanisms that differ from those of known commercial dextrans. A more pronounced inhibitory effect of the dextrans was observed for IHNV (Fig. 4). Differences in the antiviral activity against IPNV and IHNV have also been detected for other natural compounds. In a previous work the antiviral activity of several 
fractions of casein hydrolysates against fish viruses was examined (Rodríguez SaintJean et al., 2013). Significant inhibition of IHNV replication was observed in a dosedependent manner, with the selective index ranging from 30 to 32 , while the same molecules had only a moderate inhibitory activity against IPNV (antiviral index of around 3). This antiviral action is probably attributable to direct damage to the envelopes of the viruses. The IHNV is an enveloped virus that binds to a cell surface receptor through a G-protein attachment. Penetration into the cells is by endocytosis via coated pits. IPNV is a naked virus that enter the cells through vesicle uptake (Kuznar, Soler, Farias, \& Espinoza, 1995). In a previous work (Rodríguez Saint-Jean et al., 2013), we postulated that some peptides from the casein protein hydrolysates may bind to cellular surfaces and compete for the virus receptors, blocking the membrane fusion.

Here, a similar mechanism cannot be discarded. However, the fact that for both viruses the antiviral effect of the dextran was more prominent when treated with the polymer simultaneously with the virus or after viral infection $(60 \mathrm{~min})$ than when they were administrated 30 min prior to infection (Fig. 5), indicated that probably the dextrans act in a later step as effectors for the inhibition of the replication cycle. Further experiments will be required to reveal the mechanism of action of the EPS-LS and EPS-LM dextrans.

In vertebrates, interferons are secreted by host cells (including macrophages, lymphocytes, natural killer cells and fibroblasts), in response to recognition of doublestranded RNA intermediates of viruses such us IPNV and IHNV (Haller, Kochs, \& Weber, 2006). Type I IFN is produced by leukocytes and fibroblasts as a response to viral infections. Type II IFN, represented by IFN- $\gamma$, is produced by natural killer cells and T-lymphocytes in response to IL-12, IL-18, mitogens or antigens (Robertsen, 2006), 
with IFN- $\gamma$ being a key activator of macrophages for increased killing of bacterial, protozoal and viral pathogens. The mechanism of action of the dextrans is unknown, but it is feasible that they may act as immunostimulants. This assumption is based in our results, which revealed that the in vivo treatment of trout with EPS-LS $\alpha$-glucan, in addition to markedly decreasing mortality provoked by both IPNV and IHNV (Fig. 6), significantly increased the expression of IFN-1 and IFN- $\gamma$ (Fig. 7).

\section{Conclusions}

We have characterized two dextran-producing LAB isolated from fermented meat products. Their purified dextrans have shown functional activity against salmonid viruses, IPNV and IHNV. As far as we know, this work represents the first study on the identification of antiviral activity of natural dextrans against fish viruses. Further studies are required to determine the mechanisms responsible for the antiviral effect of these biopolymers. Nevertheless, our results indicate that fish-food containing the high molecular weight $\alpha$-glucan from $L b$. sakei MN1 would be effective in protection of salmonids from viral infection. In addition, its stimulatory effect on the immune response of fish through dietary supplements should have additional value for commercial aquaculture.

\section{Acknowledgements}

This study was supported by grants AGL2009-12998-C03-03, AGL2012-40084-C03-01 and CSD2007-00063 from the Spanish Ministry of Economics and Competitiveness and grants PIE2010-20E084 and PIE201320E017 from Consejo Superior de Investigaciones Científicas. We thank Dr. Stephen Elson for critical reading of the manuscript. 
Ai, Q., Mai, K., Zhang, L., Tan, B., Zhang, W., \& Xu, W. (2007). Effects of dietary B-1,

3 glucan on innate immune response of large yellow croaker, Pseudosciaena crocea. Fish Shellfish Immunology, 22, 394-402.

Ainsworth, A. J. (1994). A $\beta$-Glucan Inhibitable Zymosan receptor on Channel Catfish neutrophils. Veterinary Immunology and Immunopathology, 41, 141-152.

437 Beaulaurier, J., Bickford, N., Gregg, J. L., Grady, C. A., Gannam, A. L., Winton, J. R., \& Hershberger, P. K. (2012). Susceptibility of Pacific Herring to Viral Hemorrhagic Septicemia Is Influenced by Diet. Journal of Aquatic Animal Health, 24, 43-48.

Bootland, L. M., \& Leong, J. (1999). Infectious haematopoietic necrosis virus. In P.T.K.

Woo, \& D.W. Bruno DW (Eds.), Fish diseases and disorders viral, bacterial and fungal infections (pp. 57-121). Wallingford, UK: CAB International.

Cook, M. T., Hayball, P. J., Hutchinson, W., Nowak, B., \& Hayball, J. D. (2001). The efficacy of a commercial beta-glucan preparation, EcoActiva (TM), on stimulating respiratory burst activity of head-kidney macrophages from pink snapper (Pagrus auratus), Sparidae. Fish Shellfish Immunology, 11, 661-672.

De las Heras, A. I., Rodríguez Saint-Jean, S., \& Pérez-Prieto, S. I. (2010). Immunogenic and protective effects of an oral DNA vaccine against infectious pancreatic necrosis virus in fish. Fish Shellfish Immunology, 28, 562-570.

De Man, J. C., Rogosa, M., \& Sharpe, M. E. (1960). A medium for the cultivation of 451 Lactobacilli. Journal of Applied Bacteriology, 23, 130-135.

Dubois, M., Gilles, K. A., Hamilton, J. K., Rebers, P. A., \& Smith, F. (1956). 
Engstad, R. E., \& Robertsen, B. (1994). Specificity of a $\beta$-glucan receptor on machrophages from Atlantic salmon (Salmo salar L). Developmental and Comparative Immunology, 18, 397-408.

Falco, A., Miest, J., Pionnier, N., Pietretti, D., Forlenza, M., Wiegertjes, G. F., \& Hoole, D. (2013). $\beta$-glucan supplemented diets induce high and broad expression levels of TLR3 what explains protection conferred by these additives against viral infections in fish. Fish Shellfish Immunology, 34, 1706.

Haller, O., Kochs, G. \& Weber, F. (2006). The interferon response circuit: induction and suppression by pathogenic viruses. Virology, 344, 119-130.

Kim, Y., Ke, F., \& Zhang, Q. Y. (2009). Effect of $\beta$-glucan on activity of antioxidant enzymes and Mx gene expression in virus infected grass carp. Fish Shellfish Immunology, 27, 336-340.

467

Kuznar, J., Soler, M., Farias, G. \& Espinoza, J.C. (1995) .Attachment and entry of infectious pancreatic necrosis virus (IPNV) into CHSE-214 cells. Archive Virology $140,1833-1840$.

470 Livak, K.J., \& Schmittgen, T.D. (2001). Analysis of Relative Gene Expression Data

471 Using Real-Time Quantitative PCR and the $2^{-\Delta \Delta \mathrm{Ct}}$ method. Methods, 25, 402-408.

472 Leemhuis, H., Pijning, T., Dobruchowska, J. M., van Leeuwen, S. S., Kralj, S., Dijkstra, B. W., \& Dijkhuizen, L. (2013). Glucansucrases: Three-dimensional structures, 474 reactions, mechanism, $\alpha$-glucan analysis and their implications in biotechnology and 475 food applications. Journal of Biotechnology, 163, 250-272.

476 Micol, V., Caturla, N., Pérez-Fons, L., Más, V., Pérez, L., \& Estepa, A. (2005). The 477 olive leaf extract exhibits antiviral activity against viral haemorrhagic septicaemia rhabdovirus (VHSV). Antiviral Research, 66, 129-136. 
479 Naessens, M., Cerdobbel, A., Soetaert, W., \& Vandamme, E. J. (2005). Review 480 Leuconostoc dextransucrase and dextran: production, properties and applications. 481 Journal of Chemical Technolology and Biotechnology, 80, 845-860.

482 Notararigo, S., Nácher-Vázquez, M., Ibarburu, I., Werning, M. L., Fernández de 483 Palencia, P., Dueñas, M. T., Aznar, R., López, P., Prieto, A. (2013). Comparative 484 analysis of production and purification of homo- and hetero-polysaccharides produced 485 by lactic acid bacteria. Carbohydrate Polymers, 93, 57-64.

Pérez-Prieto, S. I., Rodríguez Saint-Jean, S., García-Rosado, E., Castro, D., Vilas, M. 487 P., \& Borrego, J. J. (2001). Antigenic properties and experimental transmission of a 488 marine birnavirus isolated from sole (Solea senegalensis) to several fish species. Veterinary Microbiology, 82, 11-25.

Poolman, B., Hellingwerf, K. J., \& Konings, W. N. (1987). Regulation of the glutamate491 glutamine transport system by intracellular $\mathrm{pH}$ in Streptococcus lactis. Journal of 492 Bacteriology, 169, 2272-2276.

493 Ring $\varnothing$, E., Olsen, R. E., González-Vecino, J. L., Wadsworth, S., \& Song, S. K. (2012). 494 Use of immunostimulants and nucleotides in aquaculture: a review. Journal of Marine 495 Science Research Development, 2, 1-22.

496 Robertsen, B (2006). The interferon system of teleost fish. Fish Shellfish Immunology,

497 $20,172-191$.

498 Rodríguez Saint-Jean, S., Borrego, J., \& Pérez-Prieto, S. I. (2003). Infectious pancreatic 499 necrosis virus: biology, pathogenesis, and diagnostic methods. Advances in Virus 500 Research, 62, 113-165. 
501 Rodríguez Saint-Jean, S., \& Pérez-Prieto, S. I. (2006). Interferon mediated antiviral 502 activity against salmonid fish viruses in BF-2 and other cell lines. Veterinary 503 Immunology and Immunopathology, 110, 1-10.

504 Rodríguez Saint-Jean, S., De las Heras, A., Carrillo, W., Recio, I., Ortiz-Delgado, J. B., 505 Ramos, M., Gómez-Ruiz, J. A., Sarasquete, C., \& Pérez-Prieto, S. I. (2012). Antiviral 506 activity of casein and $\alpha_{\mathrm{s} 2}$ casein hydrolysates against the infectious haematopoietic 507 necrosis virus, a rabdovirus from salmonid fish. Journal of Fish Diseases, 36, 467-481.

508 Rodríguez Saint-Jean, S., Pérez-Prieto, S. I., Lopez-Exposito, I., Ramos, M., De las 509 Heras, A., \& Recio, I. (2013). Antiviral activity of dairy proteins and hydrolysates on 510 salmonid fish viruses. International Dairy Journal, 23, 24-29.

511 Ruas-Madiedo, P., \& de los Reyes-Gavilán, C. G. (2005). Invited review: methods for 512 the screening, isolation, and characterization of exopolysaccharides produced by lactic 513 acid bacteria. Journal Dairy Science, 88, 843-856.

514 Sakai, M. (1999). Current research status of fish immunostimulants. Aquaculture, 172, $515 \quad 63-92$.

516 Werning, M. L., Notararigo, S., Nácher, M., Fernández de Palencia, P., Aznar, R., \& 517 Lopez, P. (2012). Biosynthesis, purification and biotechnological use of 518 exopolysaccharides produced by lactic acid bacteria. In El-Samragy (Eds.), Food 519 additives (Chapter 5, pp. 83-114). Croacia: Y. Intech. 


\section{Legends to the figures}

521 Figure 1. Exopolysaccharide production by Lb. sakei MN1 and Lc. mesenteroides RTF10 in CDMS medium during $10 \mathrm{~h}$ growth. Growth (lines) and levels of

523 exopolysaccharide production (bars).

524 Figure 2. Physicochemical characterization of dextrans. (A) IR spectrum; (B) types of 525 bonds deduced by methylation analysis; (C) dextran structure.

526 Figure 3. Molecular mass analysis of dextrans using nuclear magnetic resonance (DOSY). (A) comparison of the 2D-DOSY spectra EPS-LS and T2000 dextrans; (B) superposition of the projections shown in (A) of the signals in the diffusion dimension.

Figure 4. Antiviral activity of different concentrations of dextrans against IPNV infection of BF-2 cells (A), and IHNV infection of EPC cells (B). Symbols: black, dark grey and white bars indicate treatment of infected cells with either EPS-LS, EPS-LM or T2000 respectively. The results depicted are the average of three independent experiments. Mean values and standard deviations are shown.

534 Figure 5. Influence of addition time on antiviral activity of dextrans against IPNV 535 infection of BF-2 cells (A), and IHNV infection of EPC cells (B). Symbols: black, dark grey and white bars indicate treatment of infected cells with either EPS-LS, EPS-LM or T2000 respectively. The results depicted are the average of three independent experiments. Mean values and standard deviations are shown.

Figure 6. Antiviral protective activity of EPS-LS against IPNV (A) and IHNV (B)

540 infection of rainbow fry trout. Symbols: $\bullet$, untreated infected trout; $\boldsymbol{\Delta}$ and $\mathbf{m}$, infected trout treated with EPS-LS at 10 or $50 \mu \mathrm{g}$ per fish.

542 Figure 7. Influence of EPS-LS on expression of IFN-1 (A) and IFN- $\gamma$. Levels of RNA 543 from head kidney of trout treated with either EPS-LS (black bars) or poly I:C (white 
544 bars) were analyzed by RT-qPCR. The results depicted are the average of three 545 independent experiments. Mean values and standard deviations are shown. 
Table 1. Dextran cytotoxicity and antiviral activity.

\begin{tabular}{|c|c|c|c|c|c|}
\hline \multirow{2}{*}{ Dextran } & \multirow[b]{2}{*}{$\begin{array}{c}{ }^{\mathrm{a}} \mathrm{CC}_{50} \\
\left(\mu \mathrm{g} \mathrm{mL}{ }^{-1}\right)\end{array}$} & \multicolumn{2}{|c|}{ IPNV } & \multicolumn{2}{|c|}{ IHNV } \\
\hline & & $\begin{array}{c}{ }^{\mathrm{b}} \mathrm{EC}_{50} \\
\left(\mu \mathrm{g} \mathrm{mL}^{-1}\right)\end{array}$ & ${ }^{\mathrm{c}} \mathrm{SI}$ & $\begin{array}{c}{ }^{b} \mathrm{EC}_{50} \\
\left(\mu \mathrm{g} \mathrm{mL} L^{-1}\right)\end{array}$ & ${ }^{\mathrm{c}} \mathrm{SI}$ \\
\hline EPS-LS & $>5000$ & 1000 & $>5$ & 500 & $>10$ \\
\hline EPS-LM & $>5000$ & 1000 & $>5$ & 750 & $>6.7$ \\
\hline T2000 & $>5000$ & 3000 & $>1.7$ & 5000 & $>1$ \\
\hline T500 & $>5000$ & $>5000$ & $>1$ & $>5000$ & $>1$ \\
\hline T70 & $>5000$ & $>5000$ & $>1$ & $>5000$ & $>1$ \\
\hline T10 & $>5000$ & $>5000$ & $>1$ & $>5000$ & $>1$ \\
\hline
\end{tabular}

${ }^{\mathrm{a}} \mathrm{CC}_{50}$ is the dextran concentration at which $50 \%$ inhibition of cell growth is observed.

${ }^{b} \mathrm{EC}_{50}$ is the dextran concentration needed to inhibit the viral cytopathic effect to $50 \%$ of control value.

${ }^{\mathrm{c}} \mathrm{SI}$ selective index is the $\mathrm{CC}_{50} / \mathrm{EC}_{50}$ ratio. 
Figure(s)

Click here to download high resolution image

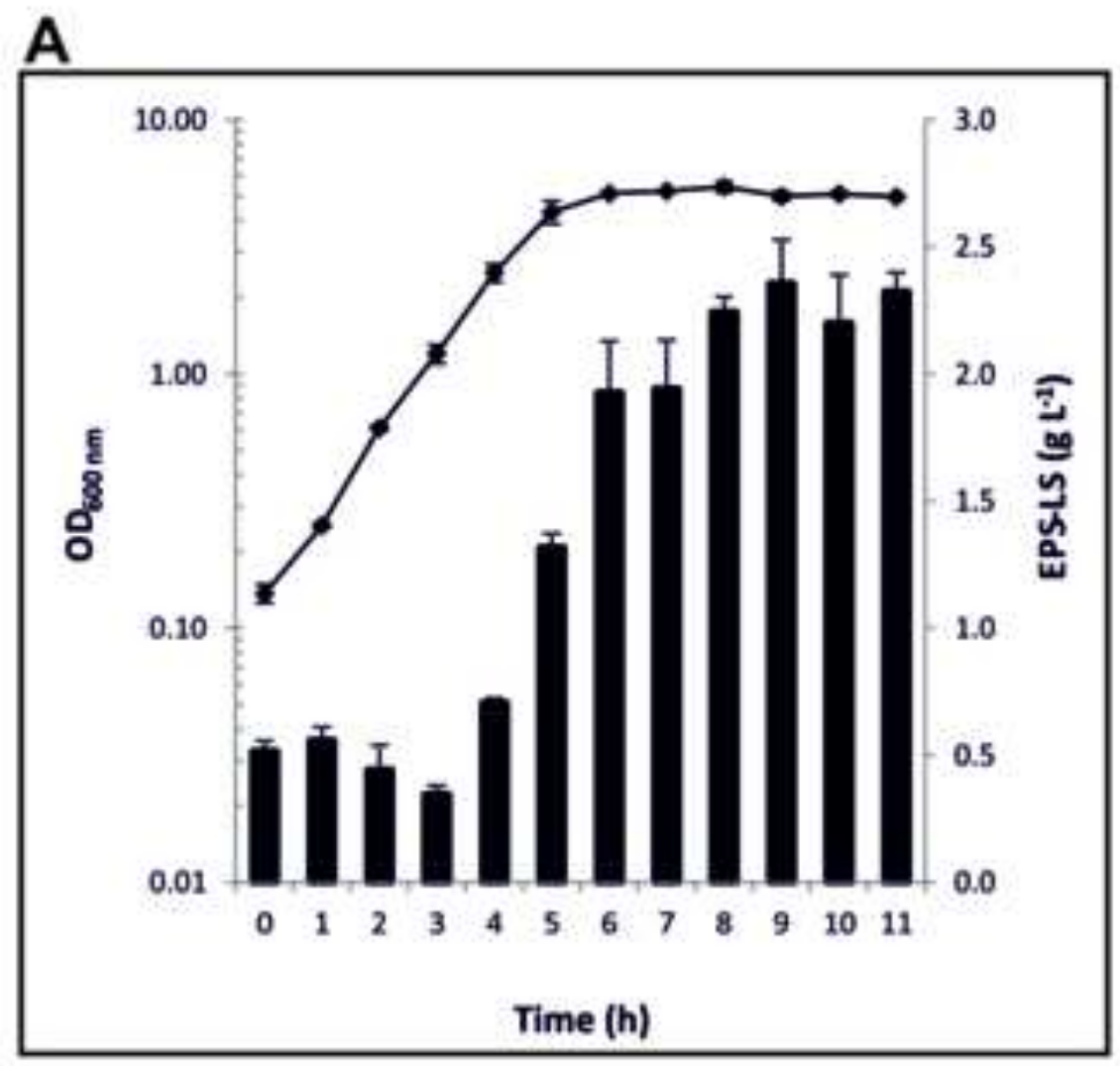

B

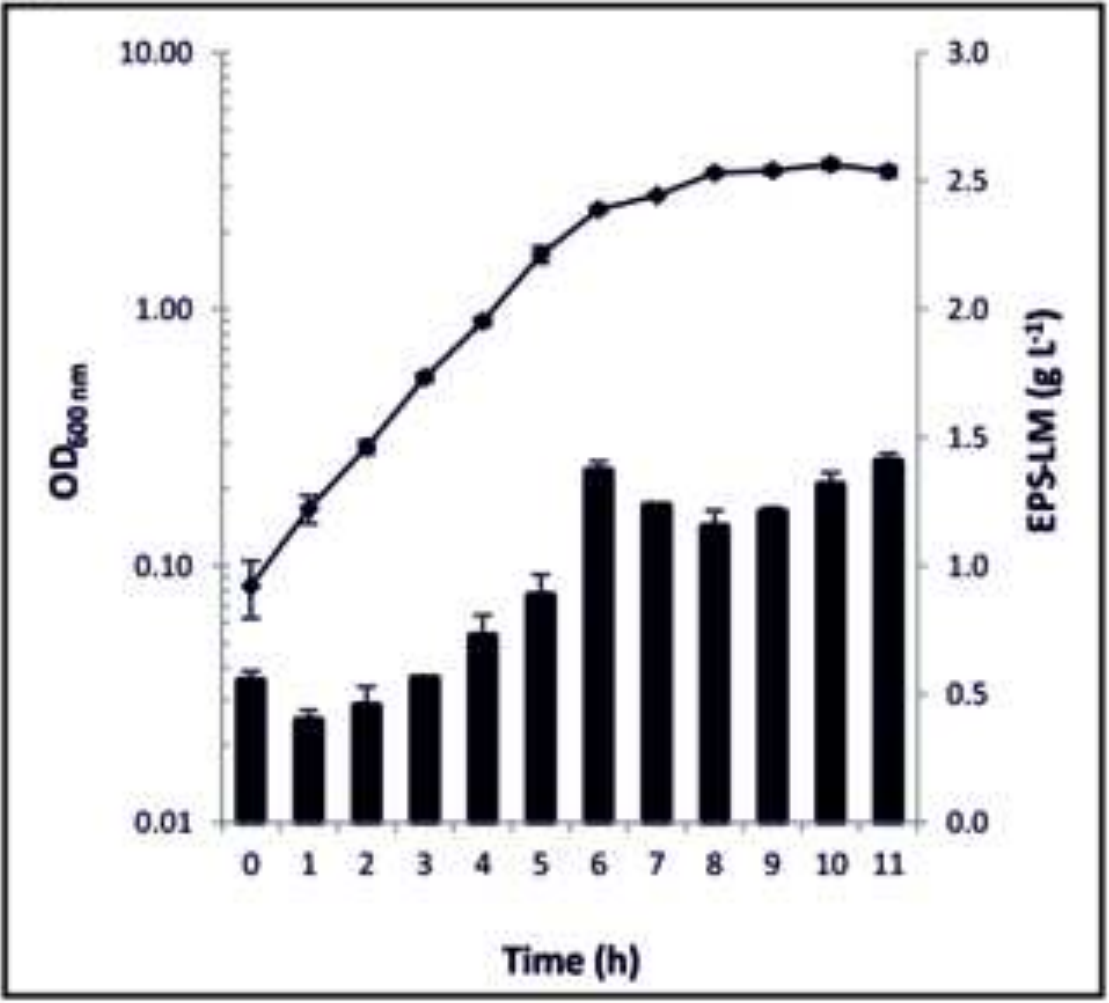

Fig. 1 


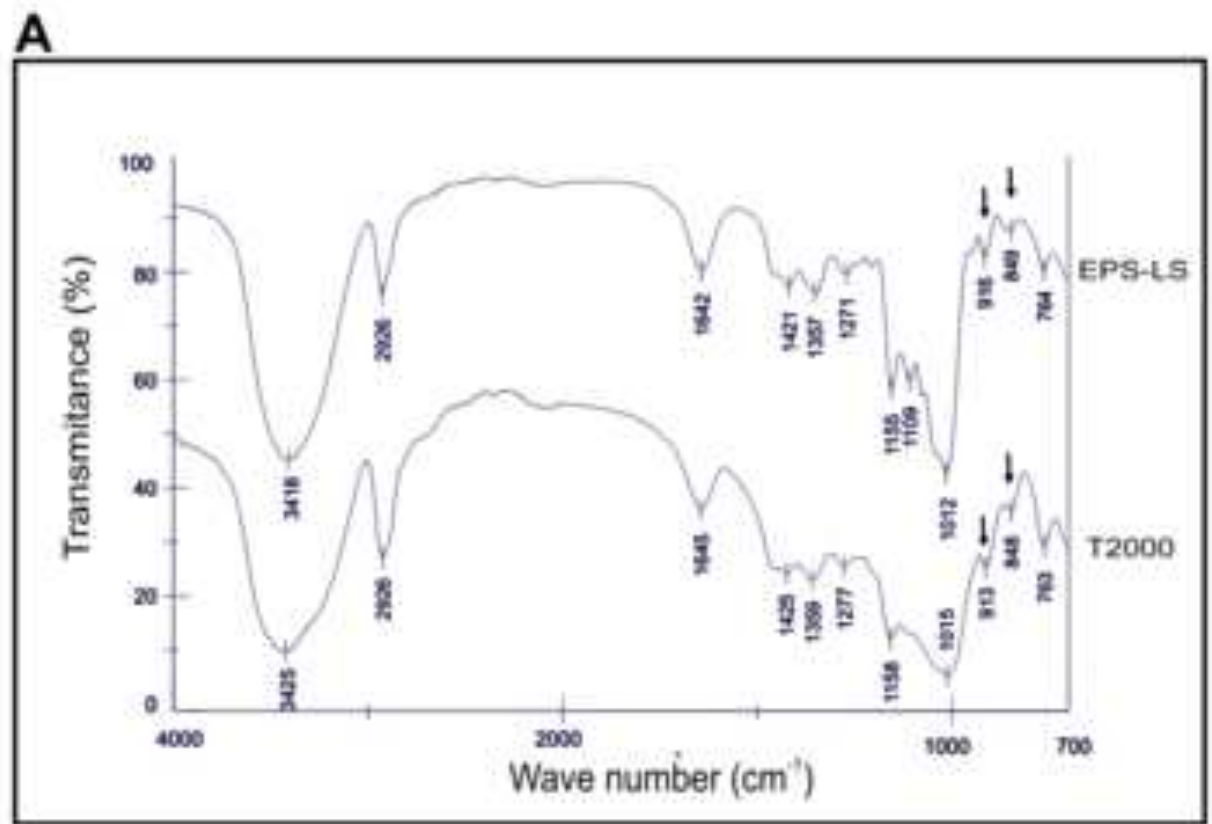

B

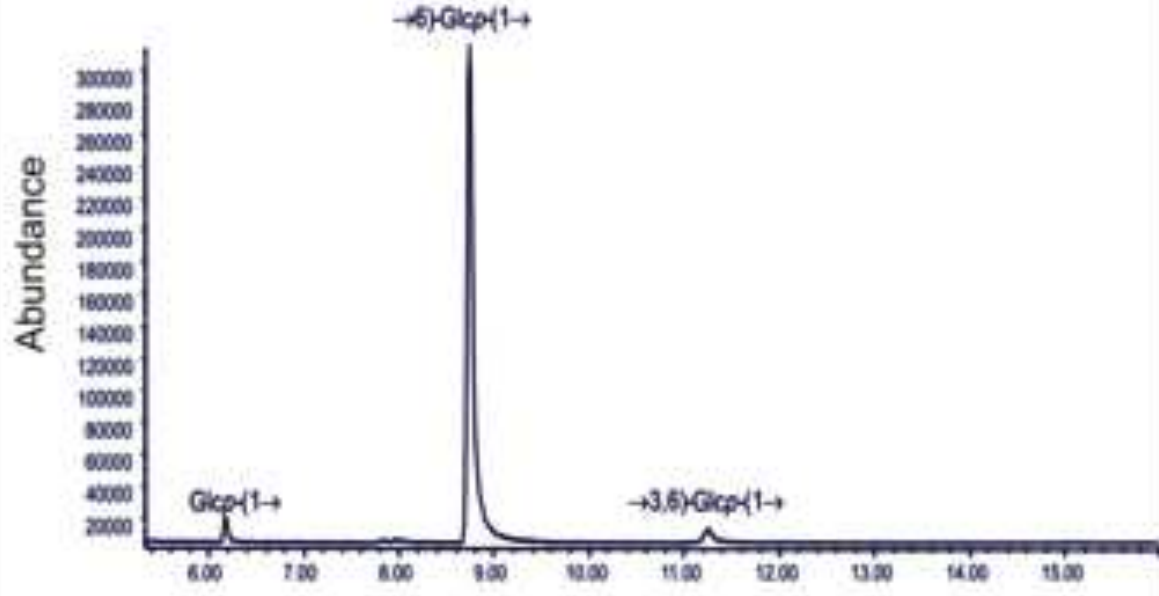

Retention time (min)

C

$\left.[\rightarrow 6)-\alpha-D-G l e p-(1 \rightarrow]_{n} \rightarrow 6\right)-\alpha-D-G l e p-(1 \rightarrow$

3

1

$\mathbf{n} \approx 90$

$\alpha$-D-Glep

Fig. 2 


\section{Figure(s)}

Click here to download high resolution image

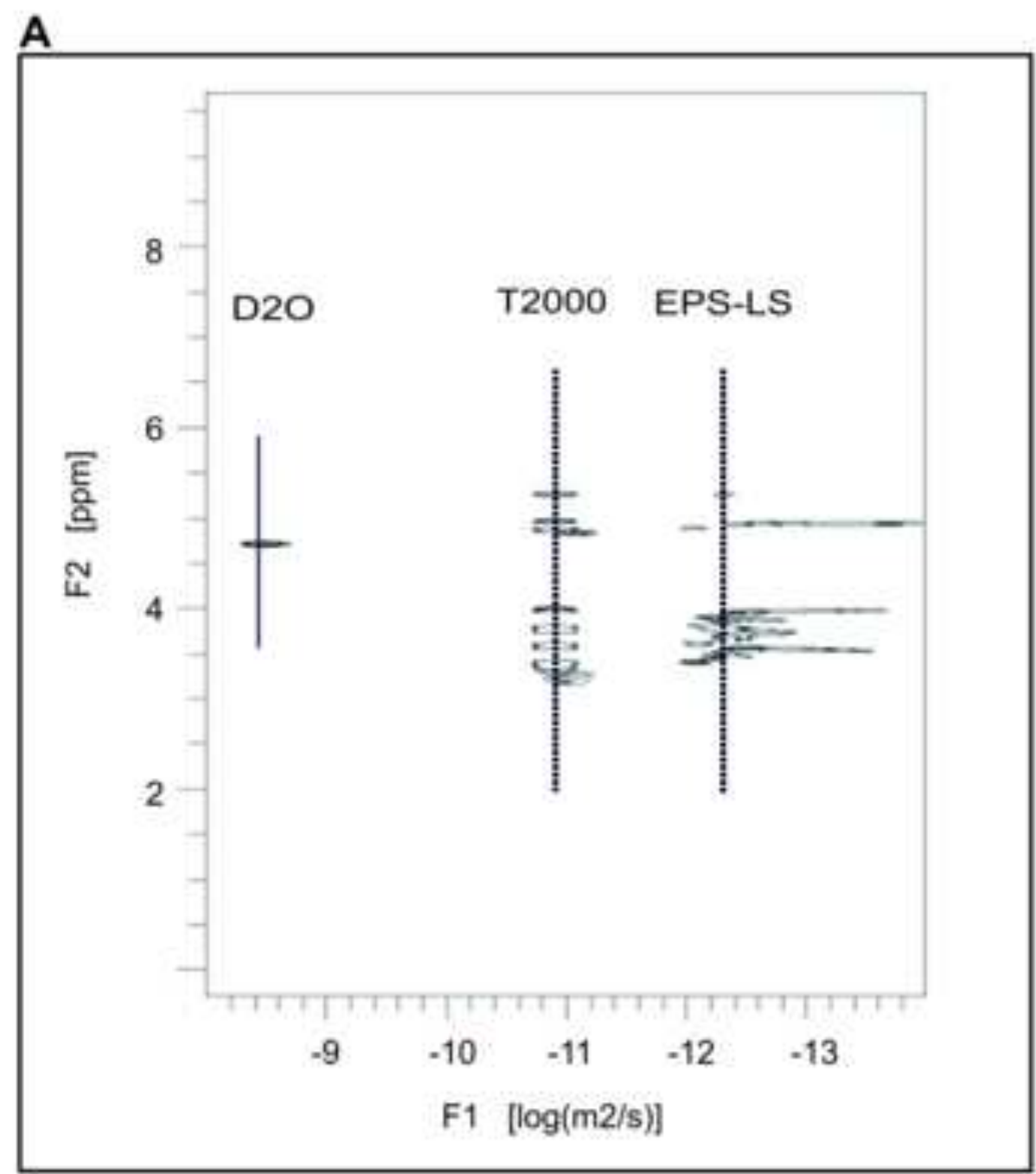

B

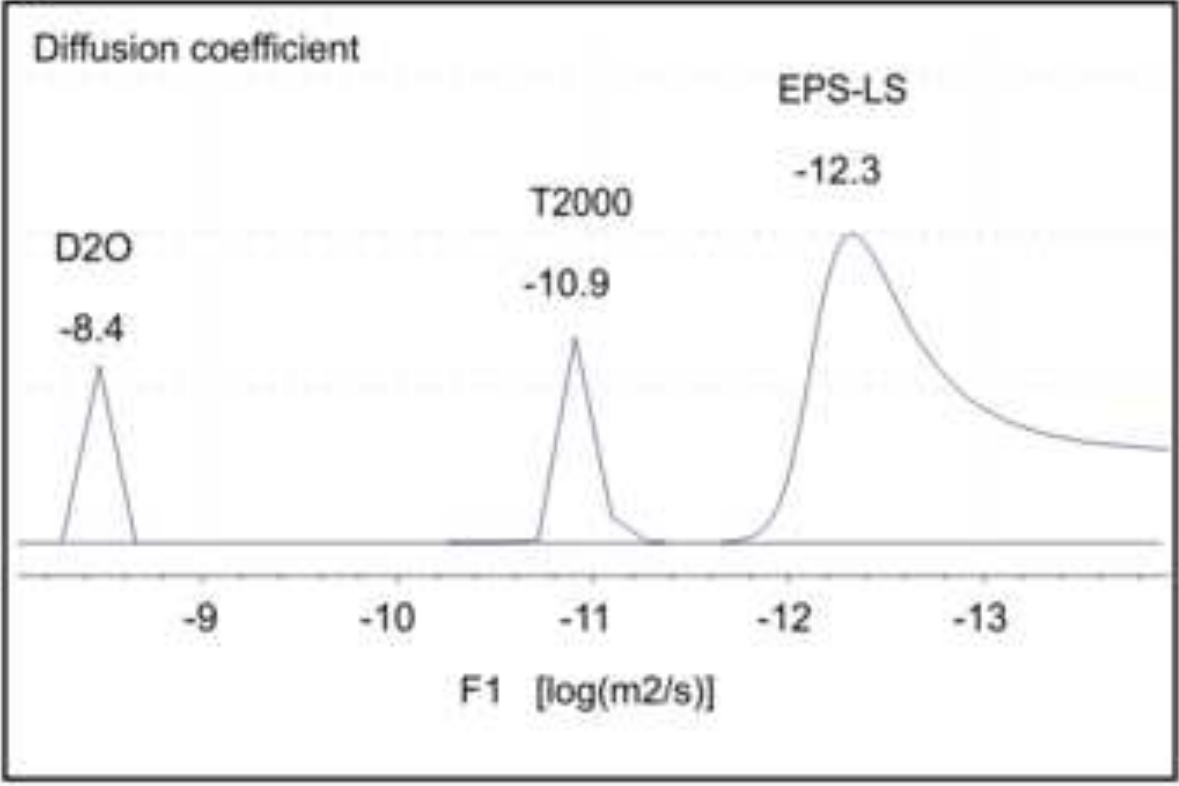

Fig. 3 


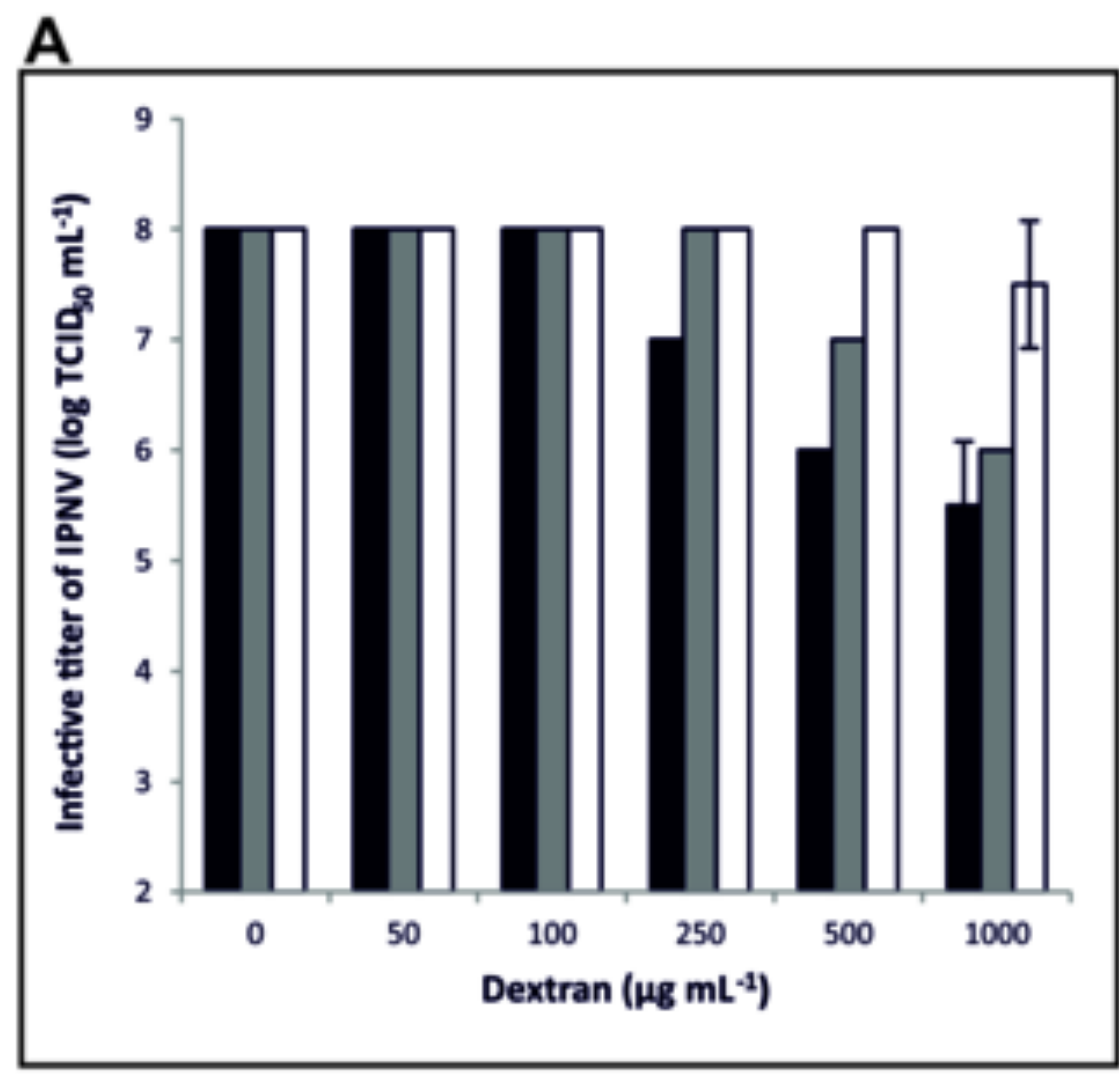

B

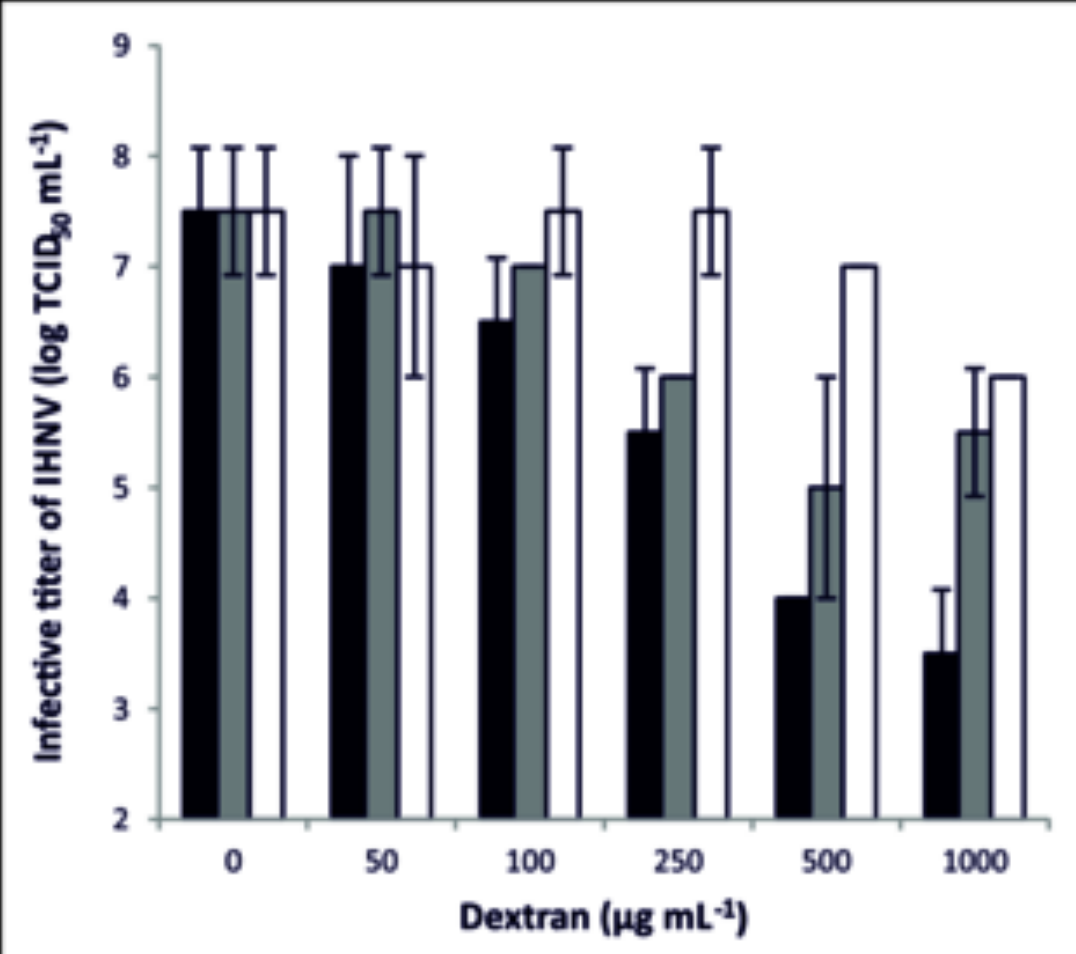

Fig. 4 
Click here to download high resolution image

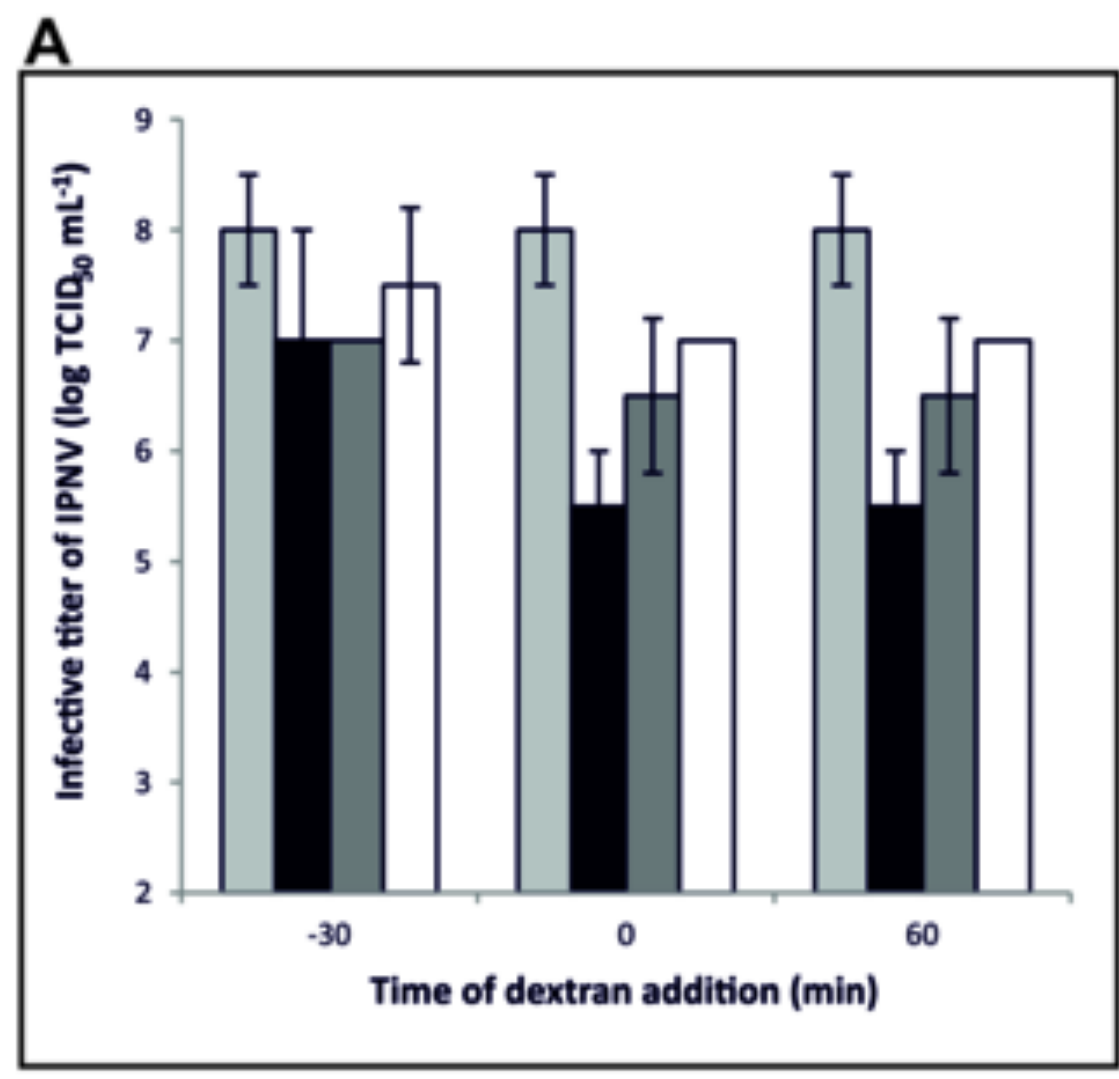

B

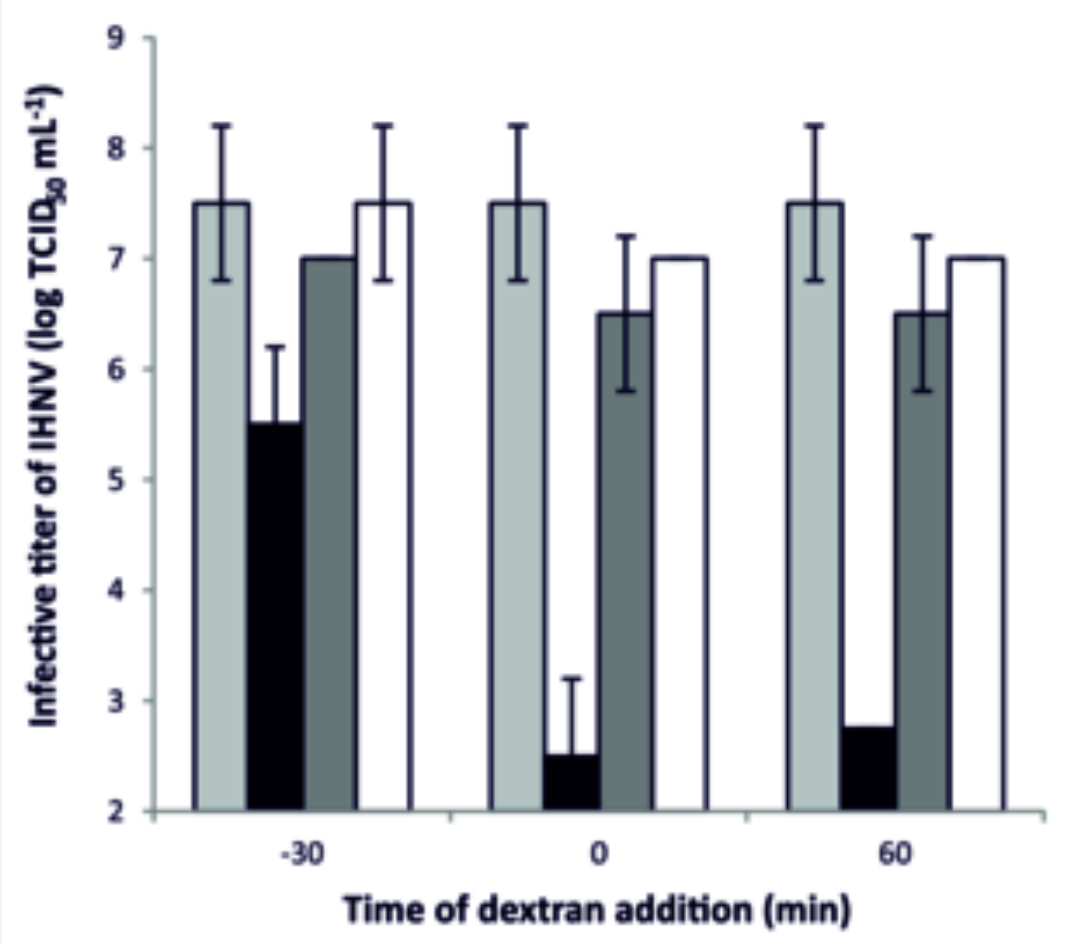

Fig. 5 
Click here to download high resolution image

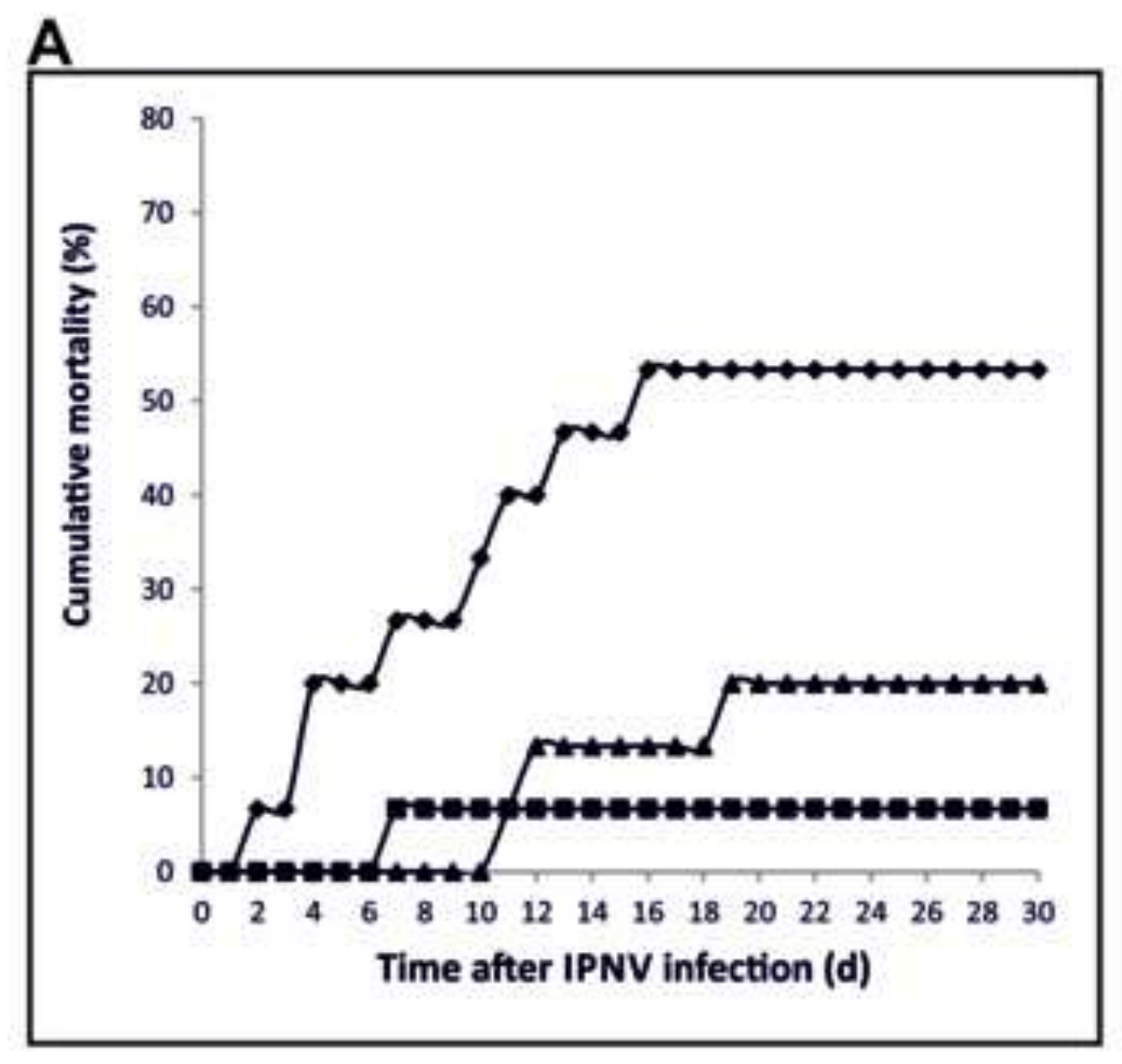

B

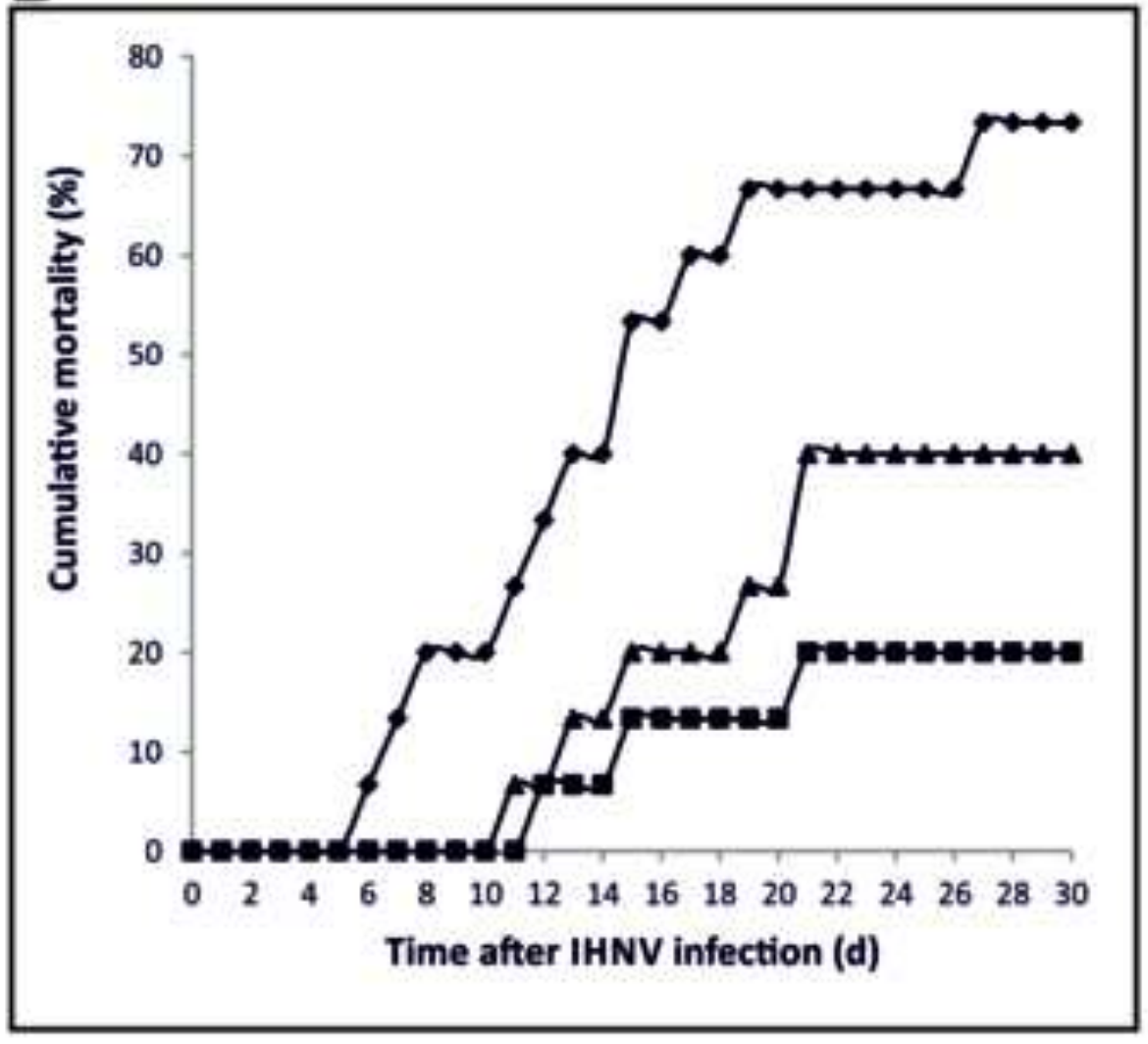

Fig. 6

Fig. 6 


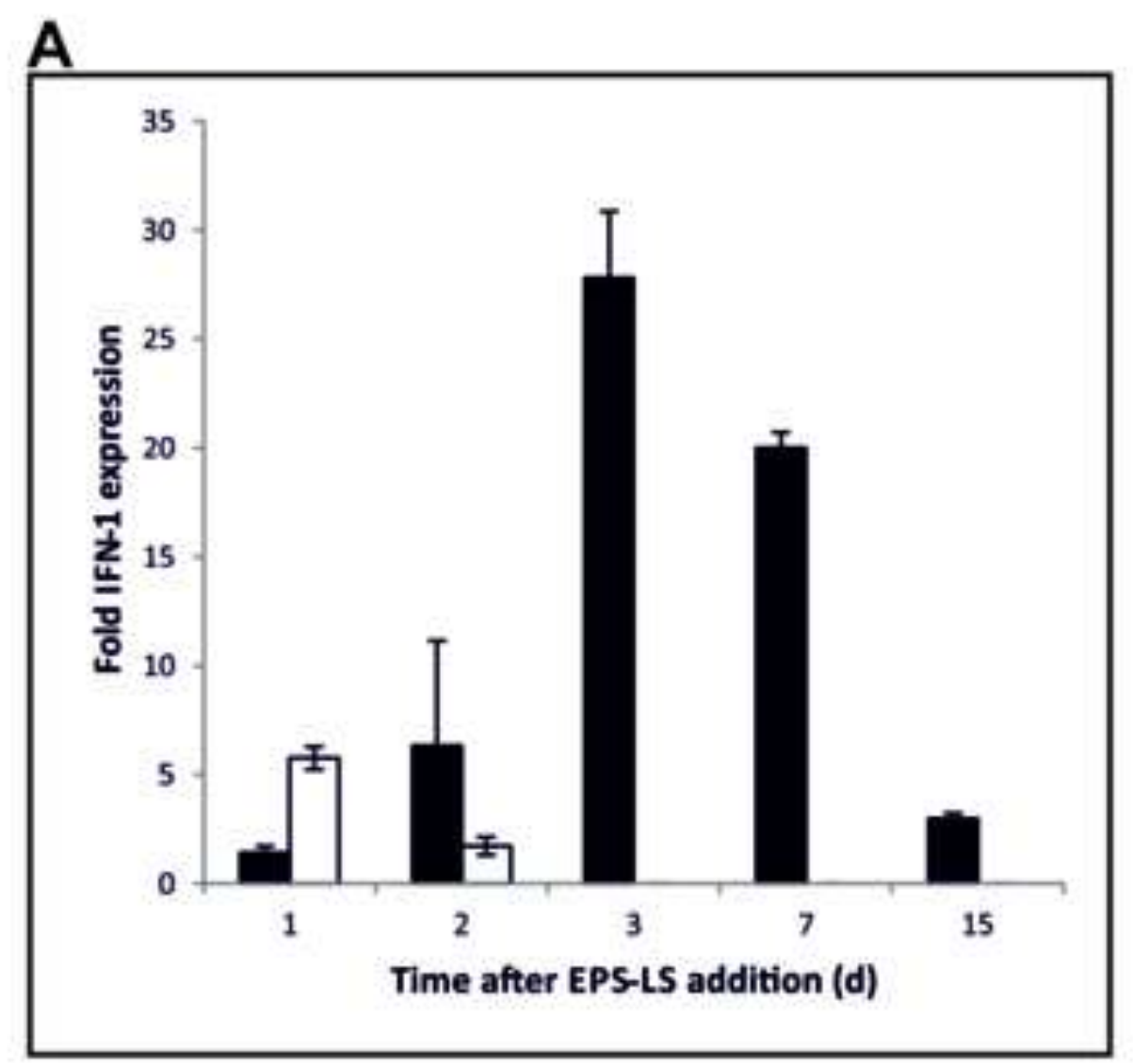

B

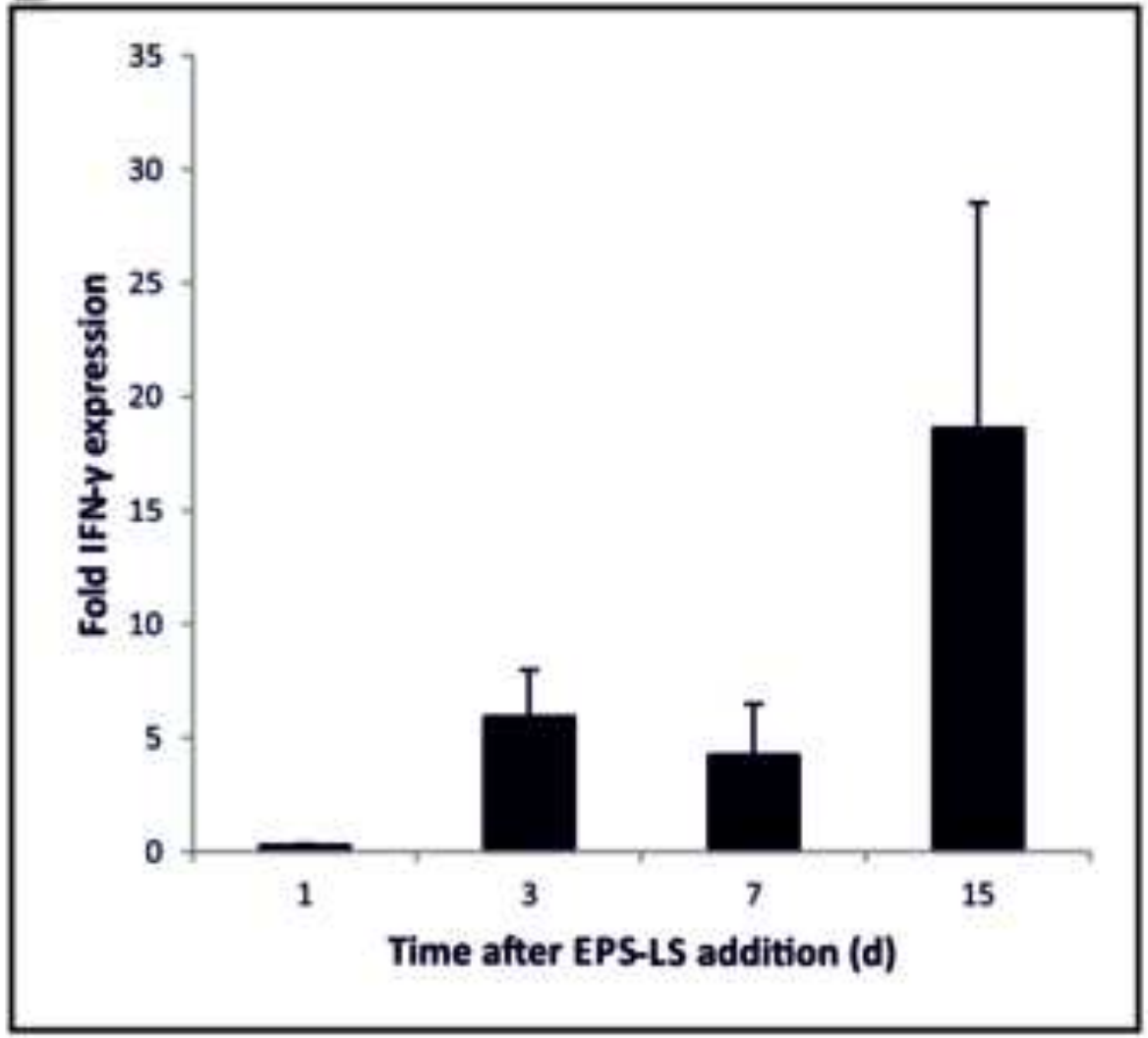

Fig. 7 
Supplementary data
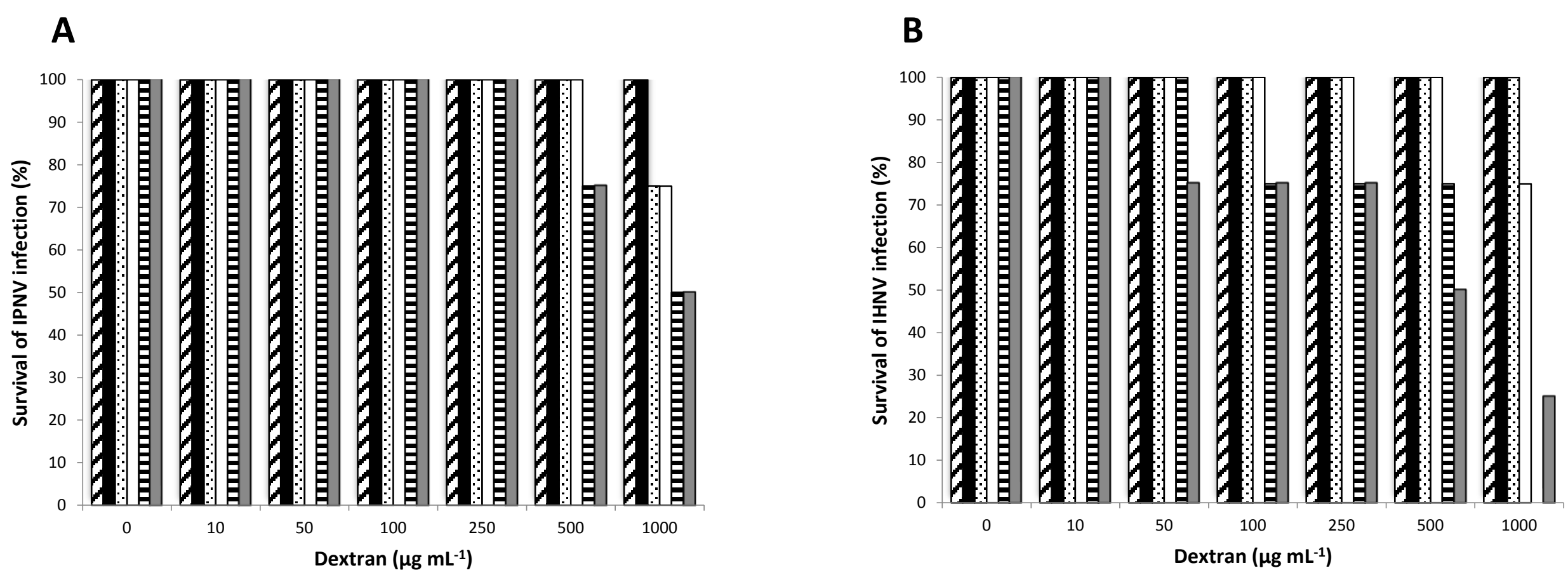

Figure 1S. Cell survival at different concentrations of dextran against IPNV infection of BF-2 cells (A), and IHNV infection of EPC cells (B). Symbols: T10 diagonal stripes, T70 black, T500 dots, T2000 white, EPS-LM horizontal stripes and EPS-LS grey. 